\title{
Modification of apoptosis-related genes and CD95 signaling in cytokine-treated astrocytes
}

\author{
Jeppe Falsig ${ }^{a, *}$, Peter Pörzgen $^{b}$, Marcel Leist ${ }^{a}$ \\ aDisease Biology, H. Lundbeck A/S, Denmark \\ bMolecular Genetics, H. Lundbeck A/S, Denmark \\ Inflammatory activation of astrocytes with a complete cytokine mix consisting of tumor necrosis \\ factor, interleukin-1 and interferon-gamma renders these otherwise resistant cells highly suscep- \\ tible to cell death induction via the CD95 pathway. In dying cells, we observed several classical \\ apoptotic features such as chromatin condensation and cytoplasmic blebbing. These events were \\ however quickly followed by a rupture of the cell membrane. For a screen of the transcriptional \\ changes taking place during the transformation from a CD95L-resistant to a CD95L-sensitive cell, \\ we employed a small custom-spotted oligonucleotide microarray. The significantly regulated mRNA \\ species were then further analyzed over a $24 \mathrm{~h}$ period by quantitative PCR. We observed a com- \\ plex pattern of transcriptional regulations showing changes of pro-apoptotic genes (cd95, caspase- \\ 8, bid, bak, caspase-11), as well as anti-apoptotic genes (c-flip, iap-1, iap-2/3, bcl-2). Since in- \\ flammatory astrocyte sensitization increased linearly with the time of cytokine-treatment the anti- \\ apoptotic genes never seemed to be able to take over a dominating role in this model. Finally, the \\ response of activated astrocytes to CD95 stimulation was compared with several other death- \\ inducing stimuli. Cells became also more sensitive towards the classical apoptosis inducer \\ staurosporine, but not towards necrotic stimuli such as $\mathrm{H}_{2} \mathrm{O}_{2}$ and $\mathrm{N}$-Methyl-N'-nitro-N-nitrosoguan- \\ idine.
}

Keywords: Apoptosis / inflammation / CD95 / microarray / Astrocytes

\section{Introduction}

Reactive astrocytes are a hallmark of most, if not all neurodegenerative diseases. The term reactive astrocyte refers to hypertrophic astrocytes expressing high amounts of glial fibrillary acid protein (GFAP) [1]. These cells are in a highly activated state producing many factors normally associated with immune cells. One marker that is associated with a certain subset of the reactive astrocytes is CD95 (Fas/Apo-1) [2]. CD95 is a member of the TNF-receptor superfamily. Generally, binding of the CD95 ligand (CD95L) to its receptor induces apoptosis, but some cells are relatively resistant and proliferative or inflammatory responses are triggered instead [3-5].

CD95 mediated apoptosis appears to play a role in several neurodegenerative diseases. Mice deficient for CD95 (Ipr) or with a defective CD95L $(g / d)$ are protected in an animal model of stroke $[6,7]$. Mice deficient for TNF and IL-1 sig-

Correspondence: Jeppe Falsig, Institut für Neuropathologie, Universität Zürich, Schmelzbergstrasse 12, CH-8091 Zürich, Switzerland. Phone: +41 1 255-3425, Fax: +41 1 2554402; e-mail: jeppe.falsig.pedersen@usz.ch naling are also protected in this model $[7,8]$ and mice defective for both TNF and CD95 signaling, show an even larger protection than mice deficient for only one of the two signaling events [7]. In autopsy cases of people who died from traumatic brain injury (TBI) the activated death inducing signaling complex (DISC), consisting of CD95, FADD, Caspase 8 and 10 can be found in the brain [9]. In a rat experimental model of TBI, CD95 and CD95L were upregulated on neurons, oligodendrocytes and astrocytes and it was found that these cells underwent apoptosis. Furthermore, activated caspase 3, 8 and 9 were found and BID was cleaved in neurons, oligodendrocytes and astrocytes undergoing apoptosis, suggesting that neurons and macroglia can express a complete apoptotic machinery [10-12].

Astrocytes are normally completely resistant to CD95 mediated cell death in vitro but it has been suggested that there is a link between inflammation and apoptosis. We have previously established an astrocyte model of inflammation, and found that CD95 was upregulated in murine astrocytes by cytokine treatment. The cells underwent a CD95 mediated

${ }^{*}$ Current address: Institute for Neuropathology, University of Zürich, CH-8091 Zürich, Switzerland. 
apoptotic-like cell death with DISC-formation, caspase activation and chromatin condensation. The strength of the inflammatory signal correlated with cell death sensitization [13]. We have now examined the mode and kinetics of the CD95 mediated cell death and used a custom spotted oligonucleotide microarray to examine transcription of apoptosis related genes in the apoptosis-sensitization phase (during cytokine-treatment).

\section{Materials and methods}

\section{Materials}

Complete cytokine mix (CCM) contained $10 \mathrm{ng} / \mathrm{mL}$ murine TNF- $\alpha, 10 \mathrm{ng} / \mathrm{mL}$ murine IL-1 $\beta$ (Sigma-Aldrich, Copenhagen, Denmark), and $5 \mathrm{U} / \mathrm{mL}$ recombinant murine IFN- $\gamma$ (RD Systems, Abingdon, UK). All laboratory chemicals were purchased from Sigma unless stated otherwise. Hamster IgG monoclonal anti-mouse CD95 antibody (JO-2) was obtained from (BD bioscience, Brøndby, Denmark).

\section{Primary astrocyte cultures}

Pregnant C57bl/6jbom mice were purchased from Harlan (Horst, Holland). All experimental procedures were carried out in accordance with the directives of the Danish National Committee on Animal Research Ethics and the European Communities Council Directive \#86/609 for care of laboratory animals.

Primary cortical astrocytes were prepared from 1-2 day old mice according to a slightly modified version of a protocol by David E. Weinstein [14]. In brief, brains from 6 pups were removed and kept on ice in a PBS buffer containing $2 \mathrm{~g} / \mathrm{L}$ glucose and $0.001 \%$ (w/v) phenol red, pH 7.4 (PBS-G). The cortices were dissected out, and hippocampi and meninges were carefully removed before digestion in PBS-G containing $10 \mathrm{mg} / \mathrm{mL}$ trypsin TRL (Worthington, Lakewood, USA), $1 \mathrm{mg} / \mathrm{mL}$ DNase (Worthington), and $5 \mathrm{mg} / \mathrm{mL} \mathrm{MgSO}{ }_{4}$ for 3 $\min$ at $37^{\circ} \mathrm{C}$. Tissue was washed in PBS-G and triturated in PBS-G with $0.5 \mathrm{mg} / \mathrm{mL}$ DNase using sequentially an 18,20 and a 23-G needle. Cells were filtered through a $70 \mu \mathrm{m}$ mesh (Falcon), pelleted (150 $\times g$ for $5 \mathrm{~min}$ ) and re-suspended in PBS-G containing DNase and $\mathrm{MgSO}_{4}$. Cells were carefully layered over a $30 \%$ Percoll solution (Amersham Pharmacia biotech, Hørsholm, Denmark) in PBS-G and centrifuged at $150 \times g$ for $10 \mathrm{~min}$.Cells were recovered from the interface, washed once with $15 \mathrm{~mL}$ PBS-G $(100 \times g$ for 5 $\mathrm{min}$ ) and re-suspended in DMEM (high glucose), 10\% FCS, $100 \mathrm{U} / \mathrm{mL}$ penicillin, and $100 \mu \mathrm{g} / \mathrm{mL}$ streptomycin. This medium was used for growing cells but for all experiments cells were changed into $2 \%$ FCS. All medium constituents were purchased from Invitrogen (Taastrup, Denmark). Cells were counted in a trypan blue solution to assess viability, and seeded at a density of 10,000 cells $/ \mathrm{cm}^{2}$ in $185 \mathrm{~cm}^{2}$ flasks (all dishes used were from NUNC, Roskilde, Denmark). Medium was changed after $3 \mathrm{~d}$, and subsequently twice a week. Cells were trypsinized and re-seeded after $14 \mathrm{~d}$ in primary culture and were always used for experiments 6-8 d after re-plating.

\section{Viability assessment}

To distinguish between viable, apoptotic and necrotic astrocytes, cells were stained with various combinations of the three fluorescent dyes Hoechst 33342, SYTOX or CalceinAM by adding the dyes 5 min prior to counting. Hoechst 33342 ( $1 \mu \mathrm{g} / \mathrm{mL}$ final conc.) is membrane permeant and stains all nuclei, whereas SYTOX $(2 \mu \mathrm{M})$ is membrane impermeant and thus only stains lysed cells. Calcein-AM is a membrane permeant dye that is loaded in viable cells but not in lysed cells. Cells with condensed nuclei but no SYTOX stain were classified as early apoptotic, cells with condensed nuclei + SYTOX stain as late apoptotic and cells with no condensed nucleus, but SYTOX stain as necrotic. At least 100 cells per field, 3 fields per well were counted using a standard fluorescent microscope.

$\mathrm{LDH}$ release was measured using a cytotoxicity detection kit (Roche) as follows: Cell culture supernatant was sampled before lysis of the cells in $0.1 \%$ Triton X-100 in medium. An equal amount of cell lysate and supernatant was incubated with the reagent mixture and after 15 minutes of incubation at room temperature the formazan product was measured spectrophotometrically at $492-690 \mathrm{~nm}$. Data are displayed as the percentage of LDH activity in the supernatant compared to total LDH activity in the well. A positive control routinely yielded a $\mathrm{LDH}$ release of $95 \%$. This value was set to $100 \%$ release and all samples was normalized to the positive control.

\section{Quantitative PCR}

Cells stimulated in 10-cm dishes were washed once with PBS and total RNA was extracted using TRIzol reagent (Invitrogen) according to the manufacturer's protocol. Purified RNA was treated with DNA-free ${ }^{T M}$, DNase-1 (Ambion, Huntingdon, United Kingdom) according to the manufacturer's protocol. Total RNA $(1 \mu \mathrm{g})$ was reverse transcribed with TaqMan RT-Reagent (Applied Biosystems, Nærum, Denmark), using random hexamers in a $100 \mu \mathrm{l}$ reaction on a PTC-200 DNA Engine Thermal Cycler (VWR international, Albertslund, Denmark), using a program of $10 \mathrm{~min}$ annealing at $25^{\circ} \mathrm{C}, 30 \mathrm{~min}$ reverse transcription at $48^{\circ} \mathrm{C}, 5 \mathrm{~min}$ inactivation at $95^{\circ} \mathrm{C}$. The cDNA was quantified using the SYBR GREEN ${ }^{\circledR}$ PCR Master Mix kit (Applied Biosystems, Nærum, Denmark). Each reaction contained $2.5 \mu \mathrm{l}$ cDNA of the $100 \mu \mathrm{L}$ RT-product, $300 \mathrm{nM}$ forward and reverse primers, $12.5 \mu \mathrm{L}$ master mix and $7 \mu \mathrm{L}$ water in a total volume of $25 \mu \mathrm{l}$. PCR amplification was run in a 96 well experimental plate 
format on an iCycler Thermal Cycler equipped with iCycler Optical System (BIORAD, Hercules, CA). The program setup was $10 \mathrm{~min}$ at $95^{\circ} \mathrm{C}, 40$ cycles of $15^{\prime}$ at $95^{\circ} \mathrm{C} / \mathrm{L}$ min at $60^{\circ} \mathrm{C}$. A melting curve was obtained to verify the measured signal and the product was run on a $4 \%$ agarose gel to verify the presence of only one band. Quantification was performed as follows: Using the iCycler data analysis software (Bio-Rad), the threshold cycle (Tc) was determined for each sample. Tc was defined as the cycle at which the level of fluorescence increased significantly above the background levels of fluorescence. The concentration of cDNA was calculated by comparing Tc of samples to Tc's of a standard curve. The standard curve was obtained by a serial dilution of cDNA. Each sample was run in two reactions, one with the primer set of interest and one with a GAPDH primer set, and all data are displayed as the ratio between the calculated starting concentration of the cDNA of interest and GAPDH. All primers except the housekeeping gene GAPDH were intron spanning in order to distinguish cDNA from genomic DNA. For GAPDH the order of magnitude between the samples and the samples without reverse transcriptase was above $10^{6}$. Primers used were GAPDH sense (Acc. No.: NM008084): 5'-TGC ACC ACC AAC TGC TTA G-3', antisense: 5'-GGA TGC AGG GAT GAT GTT C-3'. BAK sense (NM_07823): 5'-AGC CGG GAA TGC CTA CGA ACT-3', anti-sense: 5'-GCC CCA GCT GAT GCC ACT CT-3'. Bcl-2 sense (NM_09741): 5'-GGG TGA ACT GGG GGA GGA TTG T-3', anti-sense: 5'-TGT GCA GAT GCC GGT TCA GGT-3'. BID sense (NM_07544): 5'-GGC CAG CCG CTC CTT CAA C-3', anti-sense: 5'-GGG CGA GAT GTC TGG CAA TGT-3'. Caspase 8 sense (AF_67834): 5'-CAG AAA ATA ACT TGG AAA CCC TAA AAT CA-3', anti-sense: 5'GTG GCA ACT CTT CCC TTC CTT CAA-3'. Caspase 11 sense (NM_07609): 5'-ACT GAG GTA TGG GGC TAA CTT TGA CA-3', anti-sense 5'-ATC TCT GAC TCC ATG CCC TCT GCT-3'. CD95 sense (NM_07987): 5'-GCT GAG GAG GCG GGT TCG TG -3', anti-sense 5'-CAT GGG GCG CAG GTT GGT G-3'. cFLIP sense (NM_09805): 5'-CCG CCG TGC CTT TAC CTC TC-3', anti-sense 5'-CAC ACT CTG GCA AAA CAT CCG ACT-3'. IAP-1 sense (NM_07464): 5'CCC CCG GAG ATC AGA GGT CAT T-3', anti-sense 5'GGC TTC TGG TCG GTT TTA CTG CTA-3'.IAP-2 sense (NM_07465) (IAP2/3): 5'-GTC TGG CTC GTG CTG GCT TTT ATT AT-3', anti-sense 5' -TGT CCC CTT GTT TCC AGT TAT CCA-3'.Primers were designed using DNA-star software package, (DNASTAR Inc., Madison, USA) and all primers were blasted using BLASTn (http:www.ncbi.nlm. nih.gov/BLAST/).

\section{Transcript analysis by oligonucleotide hybridization analysis}

We selected a short list of mouse genes known to be upregulated in astrocyte inflammation. For each of these genes one oligonucleotide (40-50mer) was designed by MWG (MWG, Ebersberg, Germany) using their proprietary Oligo4array software and CodeSeq database, which selects the oligos preferentially from the 3 '-region of each coding sequence. Furthermore, each oligomer was scrutinized to meet physicochemical parameters (like melting temperature, self-complementarity, secondary structure etc.) and extensively tested to minimize cross-hybridization to other sequences of the mouse genome in silico. All oligos were synthesized using MWG's HPSF technology followed by MALDI-TOF quality control.

The oligomeres were spotted onto activated glass slides (Pan Epoxy, MWG or CodeLink, Amersham) using a 417 Affymetrix 'ring and pin' spotter. Sample preparation and labeling was carried out as described by Joseph DeRisi (www.microarrays.org/protocols.html), a protocol, derived from (Hughes et al. [15]). In brief: $12-15 \mu \mathrm{g}$ of total RNA were reverse transcribed using random hexamere and dT16 primers and Superscript II reverse transcriptase (Invitrogene), incorporating amino-allyl dUTP into the $1^{\text {st }}$ strand cDNA. After the cDNA synthesis, the remaining RNA was hydrolyzed and after a clean-up step (Microcon-30 spin filters, Millipore), Сy-3 or Cy-5 dye esters respectively were coupled to the cDNA samples. Excessive dye and buffer were removed with QiaQuick PCR purification columns (Quiagen) and the eluates were concentrated with Microcon-30 spin filters. The hybridization mixture contained the Cy-labeled cDNAs in hybridization buffer (50\% formamide, 6x SSC, $5 \mathrm{x}$ Denhardts, $0.5 \%$ SDS and $50 \mathrm{mM}$ sodium phosphate, $\mathrm{pH}=8$ ) and was denatured for 5 min before incubation on the slides for $16 \mathrm{~h}$ at $42{ }^{\circ} \mathrm{C}$. Washing was carried out in three steps of increasing stringency: $2 x$ SSC, $0.1 \%$ SDS followed by $1 x$ SSC, $0.01 \%$ SDS and $0.5 x$ SSC (all solutions were preheated to $30{ }^{\circ} \mathrm{C}$ ). Finally, each slide was spun dry and scanned in a 428 Affymetrix confocal laser scanner at three different intensities (photo multiplier gains).

The microarrays were analyzed using ImaGene 4.2 (BioDiscovery) for spot location, array alignment and background subtraction. Signal intensities for individual spots were adjusted for local background. Microsoft Excel was used for further statistical analysis of the ImaGene output files. E.g. Су3/Cy5 ratio normalization was carried out by multiplying each ratio value with a scaling factor, which was defined as the ratio of the overall signal intensity of the Cy5 versus Cy3 channel [16]. Each microarray experiment was performed at least twice independently. To further account for bias introduced by dye bleaching or labeling, each experiment was carried out as dye-swap experiment with the resulting ratio value being the arithmetical mean from two slides of opposite labeled sample pairs. Genes with very low signal intensities (less than 5 -fold of the background) were excluded from the analysis. 


\section{Statistics}

All results are displayed as mean \pm SD of triplicates. Array data are displayed as means of duplicates (dyeswap) \pm SD (= range). Only data from experiments confirmed at least once are displayed. One-way analysis of variance followed by the Tukey-Kramers test was used for statistical evaluation. (*: $\mathrm{P}<0.05,{ }^{\star *}$ : $\mathrm{P}<0.01$ ).

\section{Results}

We have previously shown that astrocytes become sensitive to CD95-driven cell death depending on the inflammatory state of the cell [13]. Now, we further examined the mode of cell death in non-fixed cytokine stimulated astrocytes. The cells were treated according to the stimulation scheme shown in (Fig. 1A) and stained with $\mathrm{H}-33342$, a membranepermeable chromatin dye and SYTOX, a membrane-impermeable dye. We counted cells at different times after the addition of CD95-ligand and observed an almost linear in- duction of cell death over 24 hours after ligand addition (Fig. 1B). The mode of cell death appeared to be apoptosis-like [17] since all cells dying displayed condensed chromatin as seen by $\mathrm{H}-33342$ staining. However, the vast majority of the astrocytes with condensed nuclei were also SYTOX positive (Fig. 1B $+2 B, D, F)$. Only a small population of non-lysed cells with condensed chromatin was observed at any given time point (Fig. 1B $+2 A, C, E)$.In contrast, cells were never SYTOX positive, when they had non-condensed nuclei. This suggests that chromatin condensation is very closely followed by rupture of the plasma membrane. Calcein-AM staining of the cells allowed us to study the gross cytoplasmic morphology of our cells. Viable cells were characterized by a strong cytoplasmic stain and a flat polygonal structure with fine irregular projections (Fig. 3C). CCM-stimulated cells showed many long, brightly stained, streaky cytoplasmic structures and pronounced projections (data not shown). When cells were stimulated with CCM/CD95L, dying cells first lost the fine projections and structures, then rounded off, and finally showed prominent cytoplasmic blebs (Figs.
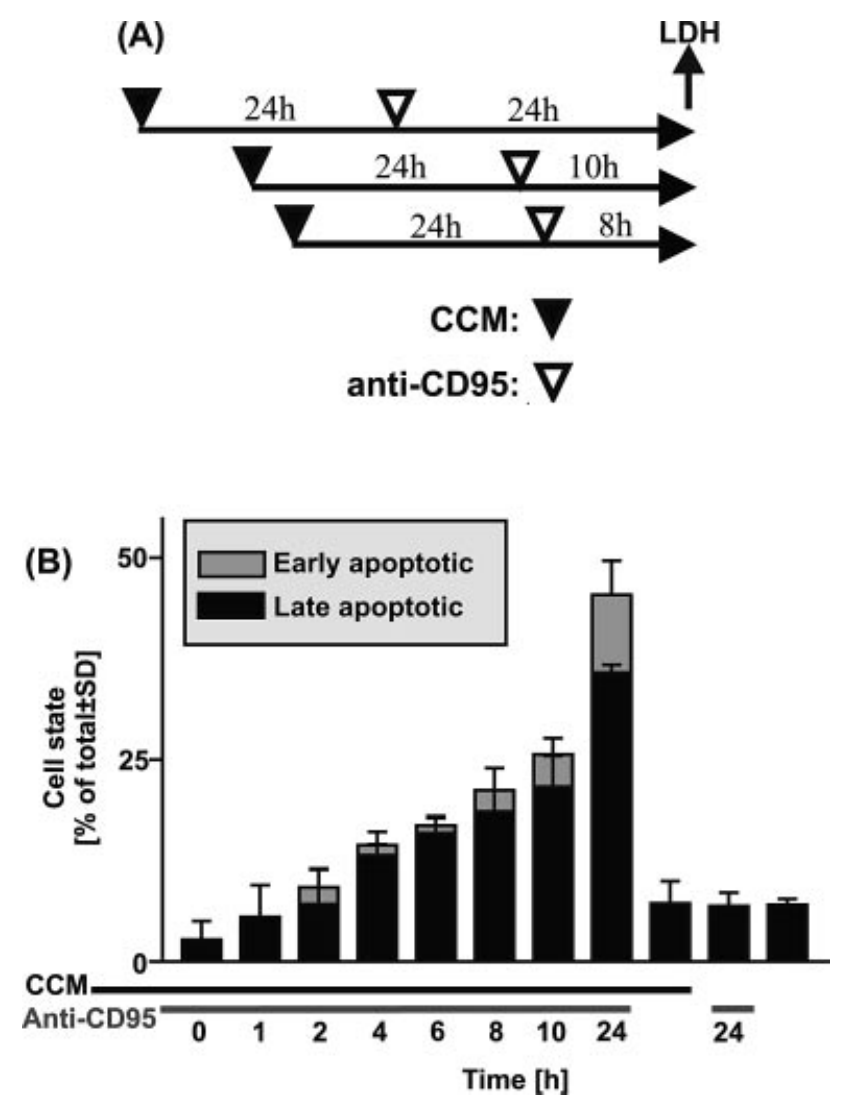

Fig. 1. Cytokine/CD95L-treated astrocytes die in an apoptosis-like fashion. The $\alpha$-CD95 antibody was added at various times to wells pre-stimulated for $24 \mathrm{~h}$ with CCM (see schematic diagram). To distinguish between viable, early apoptotic and late apoptotic astrocytes, cells were stained with various combinations of the two fluorescent dyes Hoechst 33342 or SYTOX. Cells with condensed or fragmented nucleus were scored as early apoptotic cells if SYTOX negative and as late apoptotic if SYTOX positive. Data are displayed as the means of three wells \pm SD. 


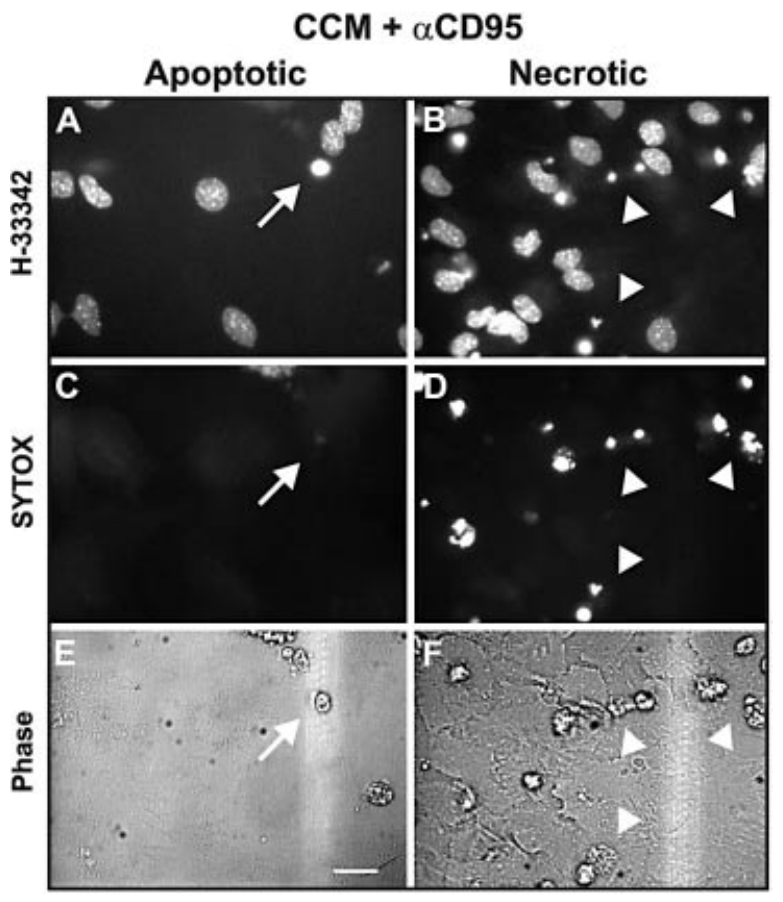

Fig. 2. Nuclear morphology of dying astrocytes. $\alpha$-CD95 antibody was added to wells pre-stimulated for 24 $\mathrm{h}$ with CCM. After further $24 \mathrm{~h}$ cells were stained with SYTOX $(2 \mu \mathrm{M})$ and H-33342 $(1 \mu \mathrm{g} / \mathrm{mL})$. A, C, E: Images taken from the same field. The arrow indicates a cell looking rounded off in phase contrast (phase), with condensed chromatin, but intact plasma membrane (SYTOX-negative). B, D, F: Images taken from the same field. Examples of late apoptotic cells (here labeled for simplicity as necrotic). Arrowheads marks cells that have an apoptotic nucleus, cytoplasmic blebs and a broken plasma membrane. Scale bar $=20 \mu \mathrm{M}$.

3B, D, F). The surviving CCM/CD95L treated cells showed morphology similar to CCM-treated cells. The apoptotic-like cell death sequence was rapidly followed by rupture of the outer cell membrane.

To further understand the sensitization process, we examined the gene regulations taking place after $4 \mathrm{~h}$ of cytokine treatment. We used a small custom-spotted oligonucleotide microarray to examine a representative set of apoptosis related genes. Besides a strong up-regulation of CD95 as described earlier [13], various other pro-apoptotic genes were

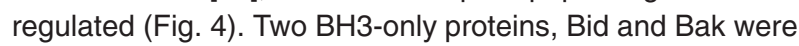
upregulated, as was caspase 11. All of the regulations were examined by quantitative PCR and followed over a time course of $24 \mathrm{~h}$. Most of the regulated genes reached peak mRNA levels after 4-8 $\mathrm{h}$ of cytokine-treatment, and the expression was decreasing towards baseline at $24 \mathrm{~h}$. However both BID and Caspase 11 remained highly expressed (Fig. 5) over the entire experimental period.

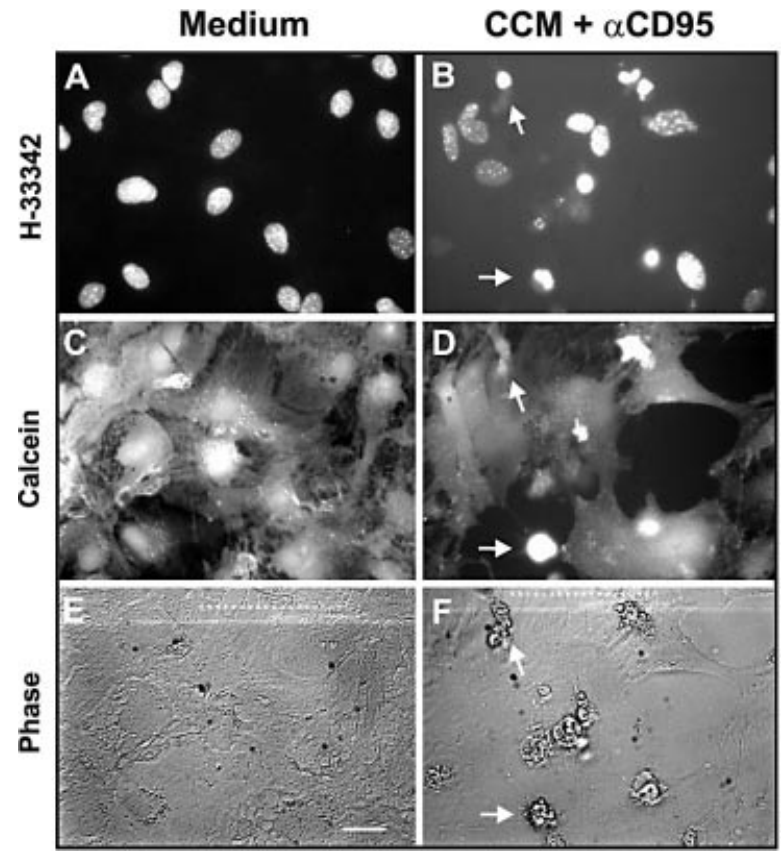

Fig. 3. Morphological examination of dying astrocytes. $\alpha$-CD95 antibody was added to wells pre-stimulated for 24 $\mathrm{h}$ with CCM. After further $24 \mathrm{~h}$, cell morphology was examined by staining the cells with Calcein-AM $(5 \mu \mathrm{M})$ and $\mathrm{H}$ $33342(1 \mu \mathrm{g} / \mathrm{mL})$. Images were taken from the same field. Arrows depict blebbing apoptotic cells. Scale bar $=20 \mu \mathrm{M}$.

Much to our surprise we also found a strong upregulation of anti-apoptotic genes. Several members of the inhibitors of apoptosis protein-family (IAP) showed increased expression (Birc-1a, 2, 3) and also cFLIP was upregulated. The regulation of cFLIP could not be confirmed with the set of primers we had initially used [13] due to a low efficiency so a new set of primers was designed and a strong signal and upregulation was confirmed (Fig. 6A). Regulations of the IAPs were also confirmed with a primer set for Birc1 and a primer set recognizing a region with equal length and $90 \%$ homology in Birc2 and 3 (Fig. 6 B, C).

Using the microarray platform, Bcl-2 was the only gene that was found downregulated. This downregulation was observed immediately after cytokine stimulation, lasting throughout the experiment (Fig. 6D), as measured by PCR. Non-regulated, apoptosis associated genes were e.g. Caspase 1-3, BAD, BAX, BIRC1e, BIRC4 and the important astrocytic apoptosis regulator PEA-15 [18] that displayed a particularly high abundance (data not shown).

In order to test whether the anti-apoptotic genes would predominate later in the cytokine/apoptosis-sensitization phase of our treatment regiment we tried increasing the cytokine pre-stimulation time from $24 \mathrm{~h}$ up to $96 \mathrm{~h}$. Such a delayed counter-regulatory response involving pro and anti-apoptotic 


\begin{tabular}{|l|c|}
\hline Fold induction: $>5$ [ald $2-5: 0.5-2 \square:<0.50$ & Fold induction \\
\hline & Ratio \\
gene name/product & $4.1 \pm 0.2$ \\
\hline FAS, CD95 & $2.0 \pm 0.2$ \\
C-Flip & $1.2 \pm 0.2$ \\
Caspase 1 & $0.9 \pm 0.2$ \\
Caspase 2 & $1.0 \pm 0.8$ \\
Caspase 3 & $0.9 \pm 0.0$ \\
Caspase 8 & $0.6 \pm 0.6$ \\
Caspase 9 & $7.2 \pm 7.3$ \\
Caspase 11 & $1.3 \pm 0.0$ \\
Bcl2-like & $0.4 \pm 0.1$ \\
Bcl2, B-cell leukemia/lymphoma 2 & $0.8 \pm 1.0$ \\
bcl2-related protein a1 & $1.0 \pm 0.2$ \\
Bcl2a1a & $1.9 \pm 2.3$ \\
Bim, Bcl2 interacting mediator of cell death & $0.9 \pm 0.0$ \\
Bad, Bcl-associated death promoter & $0.8 \pm 0.0$ \\
Bax, Bcl2-associated X protein & $2.7 \pm 1.3$ \\
Bid, BH3 interacting domain death agonist & $2.3 \pm 0.4$ \\
Bak, N-Bak, Bak1, BCL2-antagonist/killer 1 & $4.1 \pm 4.8$ \\
Baculoviral IAP repeat-containing 1a & $0.9 \pm 0.2$ \\
Baculoviral IAP repeat-containing 1e & $10.0 \pm 4.0$ \\
Baculoviral IAP repeat-containing 2 & $3.1 \pm 2.9$ \\
Baculoviral IAP repeat-containing 3 & $1.1 \pm 0.5$ \\
Baculoviral IAP repeat-containing 4 & $1.6 \pm 0.9$ \\
p53, transformation related protein 53 & $0.8 \pm 0.1$ \\
Phosphoprotein enriched in astrocytes 15 & \\
\hline
\end{tabular}

Fig. 4. Regulation of apoptosis related genes by CCM. Cells were treated for $4 \mathrm{~h}$ with CCM. Total RNA was purified and labeled cDNA was prepared. Different competitive cDNA hybridization experiments were done on a small custom array for CCM vs. Control (CTR), Data presented are the average of two dye-swap hybridizations for one cell preparation. All data are presented as means of duplicates \pm Range.

genetic changes, has been described for systems, for instance during oncogenic transformation [19]. However, we saw a direct correlation between the time cells had been activated by cytokines and how sensitive they became to undergo apoptosis (Fig. 7). Cytokine treatment itself was slightly toxic to the cells but this toxicity never surpassed $10 \%$ even after 5 days of treatment (Fig. 7). The specificity of the JO-2 antibody has previously been confirmed by heatinactivating the antibody and by using an isotypic antibody [13].

The CD95-activating antibody $\mathrm{JO}-2$, induce cell death of CCM treated astrocytes in a linear, concentration-dependent fashion, whereas control cells were not affect by anti-CD95 treatment (Fig. 8A). Thus the CCM treated astrocytes were $>100 x$ more sensitive to CD95 stimulation. To further examine the functional consequences resulting from the complex pattern of gene regulation observed, we tested whether astrocytes changed their sensitivity towards other death inducing stimuli. Astrocytes pre-treated with CCM for $24 \mathrm{~h}$ became approximately 4 times $\left(\mathrm{EC}_{50}\right.$ (control): $3.3 \mu \mathrm{M}$ vs. $\mathrm{EC}_{50}$
(A)
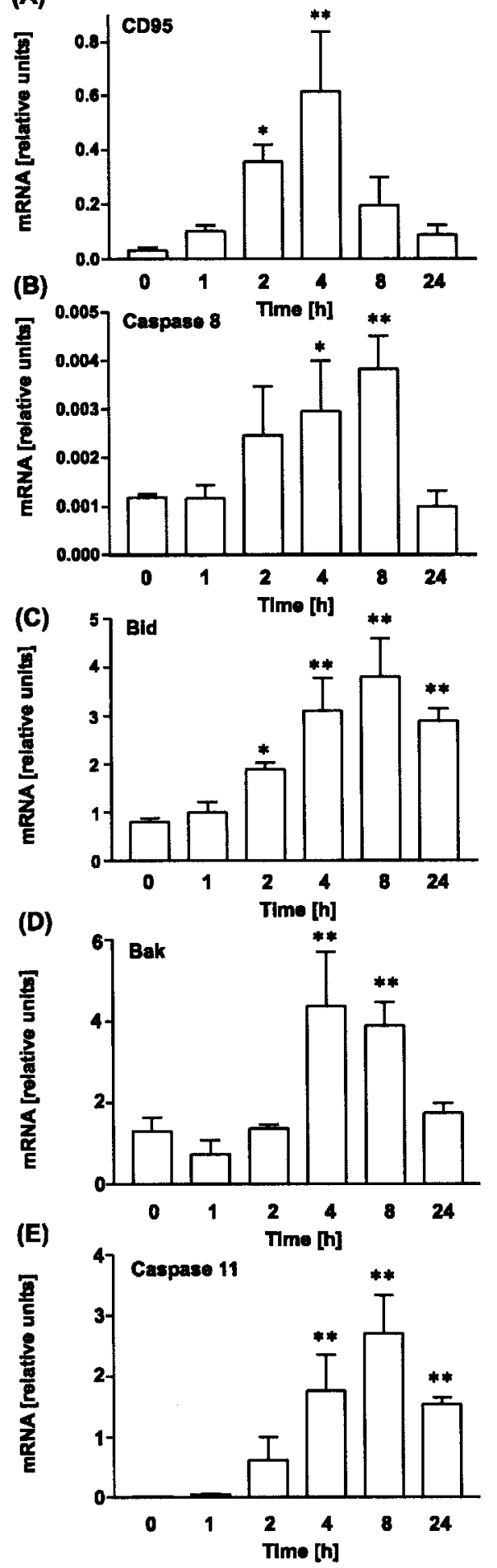

Fig. 5. Change of the pro-apoptotic signaling system by CCM.

Cells were stimulated with CCM for the times indicated; total RNA was extracted and A. CD95 B. Caspase 8 C: BID D. Bak E. caspase 11 mRNA was quantified by real-time RTPCR. Data are displayed as means of triplicates \pm SD and are displayed as the ratio of gene vs. GAPDH expression. 

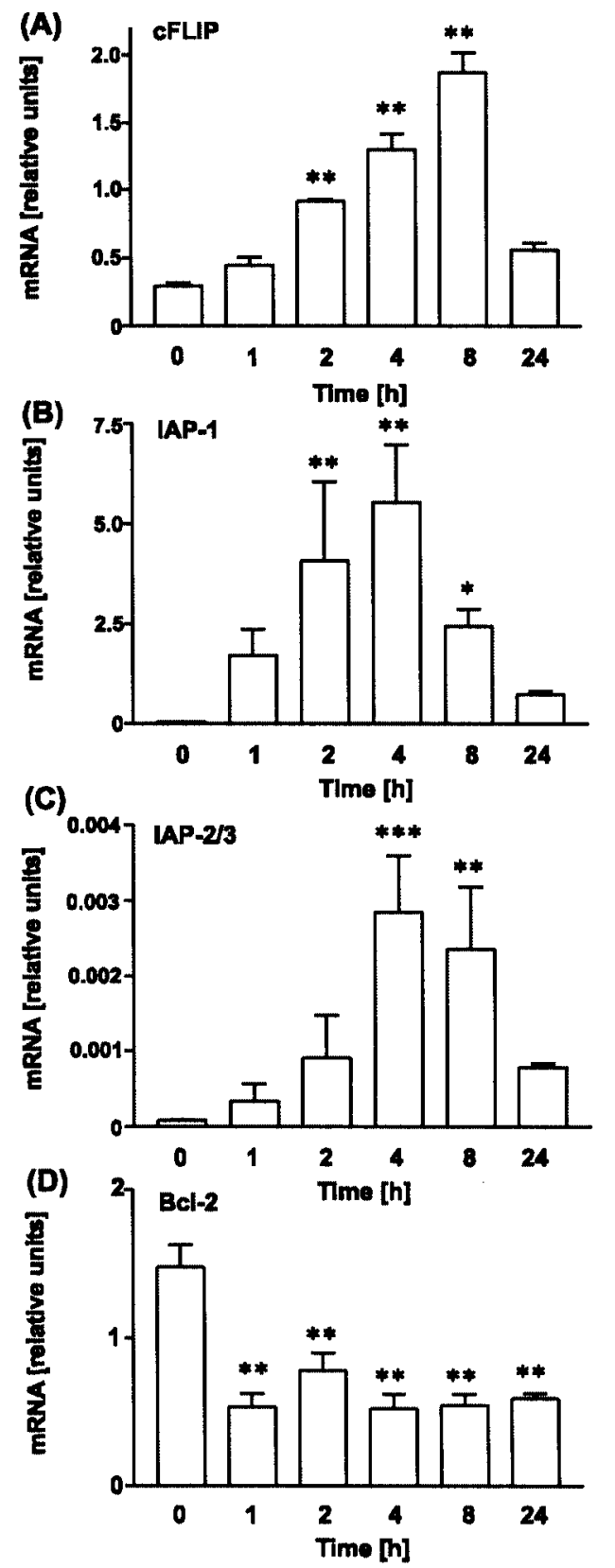

Fig. 6. Change of the anti-apoptotic signaling system by CCM.

Cells were stimulated with CCM for the times indicated; total RNA was extracted and A. cFLIP B. BIRC-1 C. BIRC-2/3 D. Bcl-2 mRNA was quantified by real-time RT-PCR. Data are displayed as means of triplicates \pm SD and are "ratio of gene vs. GAPDH".

(CCM): $0.8 \mu \mathrm{M})$ more sensitive towards staurosporine induced cell death, as measured by the release of LDH (Fig. 8B, Tab. 1). However, this was not a general death sensitization since astrocytes appeared to be slightly protected by
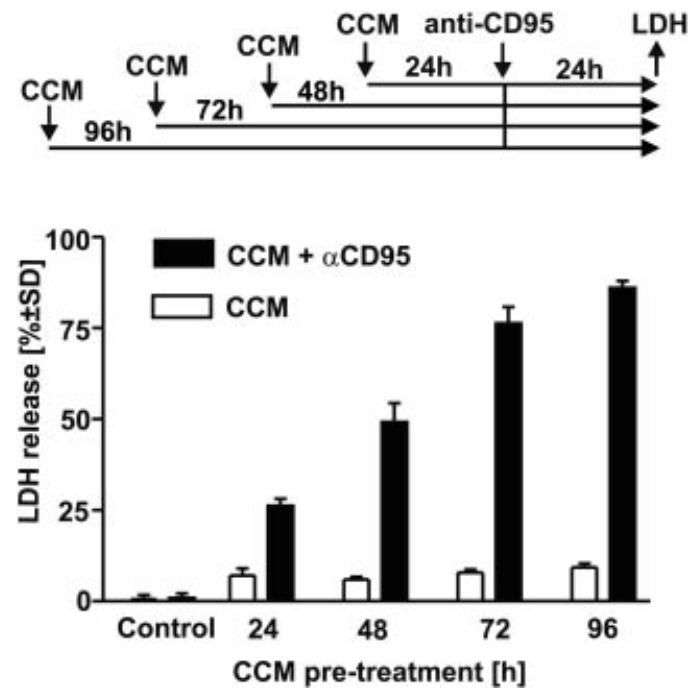

Fig. 7. Time course of cytokine-mediated apoptosis sensitization.

$\alpha$-CD95 antibody was added to cells pre-stimulated for 0-96 $\mathrm{h}$ with CCM (see schematic diagram). After $24 \mathrm{~h} \mathrm{LDH}$ release was measured. Data are displayed as mean LDH release of triplicates $\pm \mathrm{SD}$.

CCM-treatment against the necrosis-inducing stimulus $\mathrm{H}_{2} \mathrm{O}_{2}$ (control): $92 \mu \mathrm{M}$ vs. $\left.\mathrm{EC}_{50}(\mathrm{CCM}): 169 \mu \mathrm{M}\right)$ (Fig. 8B). A similar tendency of slight protection was also observed with CCMtreated astrocytes when exposed to N-Methyl-N'-nitro-N-nitrosoguanidine (MNNG) (Fig. 8B).

\section{Discussion}

In this study we present data showing that reactive astrocytes undergo an apoptotic-like cell death after treatment with CD95L and that the sensitivity increases linearly with the time of cytokine pre-treatment. Furthermore, we show a complete time course of expressions of apoptosis regulating genes, which form a complex pattern as basis for changed cellular sensitivity. We examined the cell death and found that astrocytes die with a slow kinetics after CD95 ligation. Most of the cells had condensed nuclei and perforated cell membranes. This could suggest that the cells undergo an apoptotic-like cell death characterized by quick rupture of the outer membrane following nuclear condensation [17]. An alternative explanation could be that there are two populations of cells, one undergoing an apoptosis-like cell death program at earlier times and a second one undergoing apoptosis at later times. This would be in agreement with the fact that caspase activity was only observed after CD95ligation at a time when a certain population of cells had already died [13]. The population of cells dying was increased after prolonged cytokine pre-treatment followed by CD95Ltreatment. However, cytokine treatment alone was not signif- 

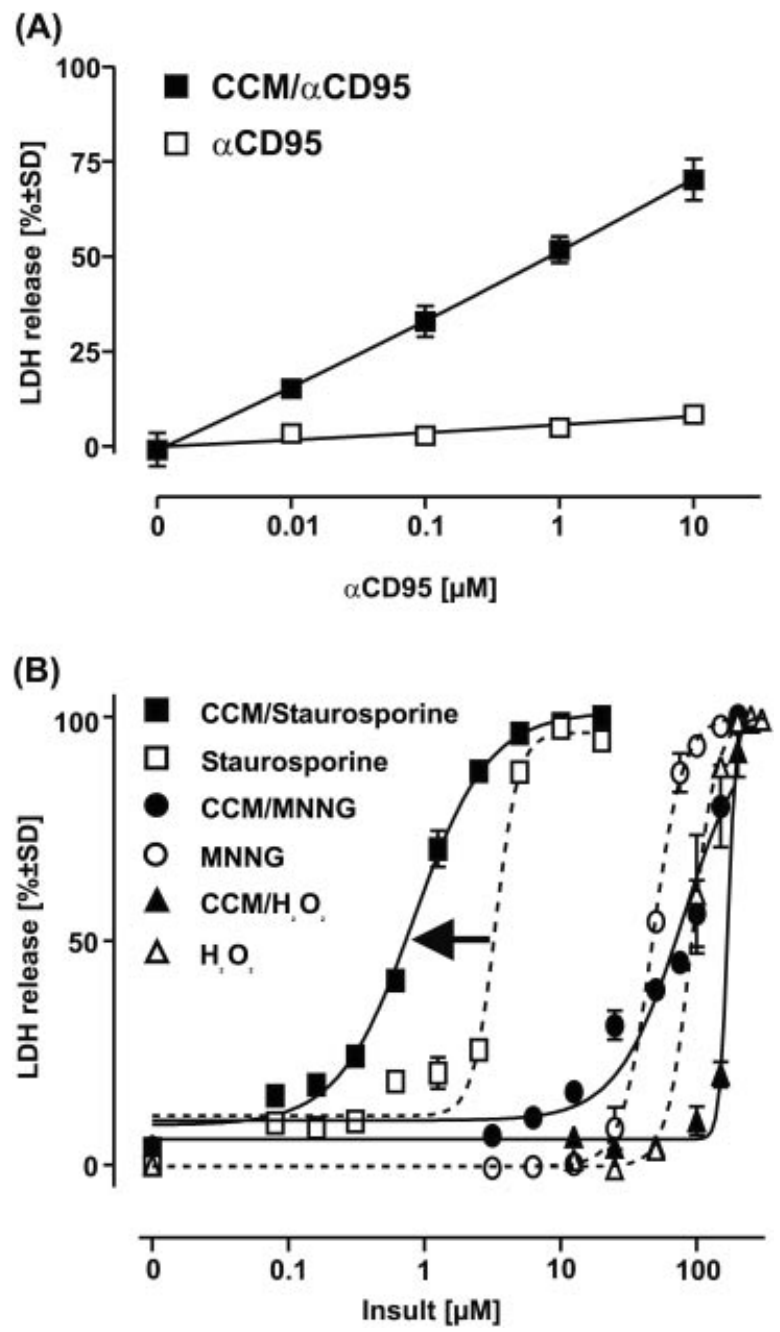

Fig. 8. Cell death sensitivity of reactive astrocytes.

A. $\alpha$-CD95 antibody was added to cells pre-stimulated for $24 \mathrm{~h}$ with CCM. After $24 \mathrm{~h}$ LDH release was measured. B. Different death-inducing stimuli (Staurosporine (squares), hydrogenperoxide (triangles) or MNNG (circles)) were added to cells pre-stimulated for $24 \mathrm{~h}$ with CCM (solid symbols and lines) and to non-stimulated cells (open symbols and dotted lines) in parallel. After $24 \mathrm{~h}$, LDH release was measured. Data are displayed as mean $\mathrm{LDH}$ release of triplicates \pm SD.

icantly toxic to the cells. It has been shown in rat astrocytes that a "cytokine-cocktail" similar to ours induced caspase 11 and that this lead to a CD95-independent cell-death on its own [20]. We did see a strong upregulation of caspase 11 (on the transcriptional level), but in our cell system the cellviability was not significantly affected by the cytokine treatment. This is possibly due to an upregulation of the inhibitors of apoptosis proteins and a resulting, balance of pro and anti-apoptotic factors.

The transcriptional profile of our cells strongly suggests that the balance of $\mathrm{Bcl}-2$ family proteins may play a role in the apoptosis program. Bid, a link between the CD95 pathway and the mitochondria was strongly upregulated as was Bak its interaction partner. Bcl-2 (an antagonist of Bak) was downregulated. This is corroborated by our data showing that astrocytes become more susceptible to staurosporine induced cell death after CCM treatment. Astrocytes are normally more resistant than neurons to this fungal toxin that induces apoptosis via the mitochondrial pathway, but after CCM-treatment astrocytes show approximately the same sensitivity as neurons. However, also at the level of the receptor, strong upregulation of different factors was observed. CD95, caspase 8 and cFLIP were all upregulated. This confirms earlier reports from related models, which found an interaction of inflammatory pathways and the CD95 death receptor system [20-22]. Caspase 8 has previously been shown to be upregulated by PCR [13], but the sensitivity of our array was not sufficient to pick up the regulation most likely due to a low expression of caspase 8 (Fig. 4B).

Cytokine treatment does not appear to render astrocytes sensitive to all types of cell death, but rather switch the death sensitivity towards apoptosis. This is suggested by the fact that sensitivity towards the classical apoptosis inducers CD95 and staurosporine goes up, while the sensitivity towards $\mathrm{H}_{2} \mathrm{O}_{2}$ and MNNG, two inducers of PARP-1 mediated necrotic cell death [23], goes down. An alternative explanation, at least in the case of $\mathrm{H}_{2} \mathrm{O}_{2}$ is that cytokine-stimulated astrocytes upregulate genes involved in an anti-oxidant response (manuscript submitted).

In general, CD95/CD95L expression and function seems to be linked very much to inflammation within the brain. CD95ligation on astrocytes induces release of chemokines or cytokines [5, 21, 24] and cytokine treatment makes the cells sensitive to apoptosis $[5,13,21,25,26]$. The role of upregulation of the CD95 system on astrocytes is frequently neglected in the literature on neurodegenerative diseases. We compiled here the extensive evidence on the role of CD95/ CD95L within the brain as a discussion background for our findings. Expression of both CD95 and CD95L is increased on astrocytes, in numerous neurodegenerative diseases with inflammatory components (see Tabs. 1 and 2). Many reports show caspase activity and cell death but there are also few reports of caspase activation without the presence of cell death (Creutzfeld-Jakobs disease). There is convincing evidence for a direct involvement of the CD95/CD95L system in acute inflammatory diseases such as TBI and stroke [6, 7, 10-12] but there is also mounting evidence in chronic inflammatory disease such as MS and Alzheimer's disease (see Tab. 1). It is more difficult to assess cell death in a slowly progressing disease, but none the less it would be interesting to see how CD95 inactivation would affect the course of disease in an Alzheimer's model.

In summary, our data confirm the strong link between inflammation and apoptosis in primary astrocytes cultures. Fur- 
Tab. 1. Regulation of CD95 in CNS-related diseases.

\begin{tabular}{|c|c|c|c|c|}
\hline & $\begin{array}{l}\text { Cell-type } \\
\text { (CD95 regulation) }\end{array}$ & Species & Comments & Ref. \\
\hline Alzheimer's disease & $\begin{array}{l}\text { Neurons } \uparrow, \text { Astrocytes } \uparrow, \\
\text { White matter glial } \\
\text { cells } \uparrow\end{array}$ & hu, mu & $\begin{array}{l}\text { Caspase } 8 \text { activation, neurodegeneration } \\
\text { and increased CD } 95 \text { expression is seen } \\
\text { around plaques. Neurons purified from } L p r \\
\text { and } g / d \text { mice are protected from } A \beta_{1-42} \text { in } \\
\text { vitro and a blockade of CD } 95 \mathrm{~L} \text { shedding } \\
\text { by inhibition of metalloproteinases } \\
\text { exacerbate the } A \beta_{1-42} \text { induced damage. }\end{array}$ & {$[2,27-31]$} \\
\hline $\begin{array}{l}\text { Down syndrome and Pick's } \\
\text { disease }\end{array}$ & $\begin{array}{l}\text { Astrocytes } \uparrow, \text { Neurons } \uparrow \\
\text { (Pick's not specified) }\end{array}$ & hu & Frontal/temporal lobe, Cerebellum & {$[32,33]$} \\
\hline Ischemia/stroke & Neurons $\uparrow$, mRNA $\uparrow$ & ra, mu, hu & $\begin{array}{l}\text { Lpr mice have decreased infarct volume } \\
\text { (MCAO). Hypothermia decrease infarct, } \\
\text { CD95 and Caspase } 3 \text { expression in the } \\
\text { penumbra (MCAO). DISC formation } \\
\text { (4VO). Global cerebral ischemia (cardiac } \\
\text { arrest) decreased overall CD95 levels. } \\
\text { Human CSF levels of soluble CD95 } \\
\text { (sCD95) negatively correlated with infarct } \\
\text { volume, IL-1, IL-6, IL-10 and GM-CSF. }\end{array}$ & [34-39] \\
\hline $\begin{array}{l}\text { Pontosubicular neuron } \\
\text { necrosis }\end{array}$ & Neurons $\uparrow$ & hu & TUNEL stain positive neurons & {$[40]$} \\
\hline $\begin{array}{l}\text { Kainate or Lithium- } \\
\text { pilocarpine-induced } \\
\text { seizures }\end{array}$ & Neurons $\uparrow$ & ra & $\begin{array}{l}\text { Co-localises with TUNEL, p53, apoptosis- } \\
\text { linked markers and NeuN }\end{array}$ & {$[41,42]$} \\
\hline Traumatic brain injury & $\begin{array}{l}\text { Astrocytes } \uparrow, \\
\text { Oligodendrocytes } \uparrow, \\
\text { Neurons } \uparrow\end{array}$ & hu, mu, ra & $\begin{array}{l}\text { DISC formation (human), Caspase } 3,8,9 \text {, } \\
10 \text { activation, Bid cleavage and increased } \\
\text { CSF levels of SCD } 95 .\end{array}$ & $\begin{array}{l}{[9,11} \\
12,43]\end{array}$ \\
\hline Spinal chord compression & Not specified $\uparrow$ & ra & $\begin{array}{l}\text { CD95 positive glia cells undergo apoptosis } \\
\text { and have activated caspase } 3,8 \text {. }\end{array}$ & {$[44,45]$} \\
\hline MS/EAE & $\begin{array}{l}\text { Microglia } \uparrow, \\
\text { Oligodendrocytes } \uparrow, \\
\text { Endothelial cells } \uparrow \\
\text { Astrocytes } \uparrow\end{array}$ & hu, mu & $\begin{array}{l}\text { CD95 is up during early acute phase of } \\
\text { EAE. Lpr and gld mice show a } \\
\text { monophasic course (wt show chronic/ } \\
\text { relapsing) and lower incidence of disease. } \\
\text { Macrophages that have ingested CD95- } \\
\text { positive cells are found. }\end{array}$ & $\begin{array}{l}{[2,26} \\
46-48]\end{array}$ \\
\hline $\begin{array}{l}\text { Virus induced } \\
\text { demyelination. }\end{array}$ & Astrocytes $\uparrow$ & $\mathrm{mu}$ & $\begin{array}{l}\text { Astrocytes infected with Theiler's murine } \\
\text { encephalomyelitis virus can present } \\
\text { antigens to CD4+ cells that release IFN. } \\
\text { This sensitises astrocytes that die by } \\
\text { CD95 driven apoptosis in vitro and in vivo. }\end{array}$ & {$[49]$} \\
\hline Bacterial meningitis & Not specified $\uparrow$ & hu & $\begin{array}{l}\text { Increased levels of SCD95 in CSF of } \\
\text { patients with bacterial but not viral } \\
\text { meningitis or MS. }\end{array}$ & {$[50]$} \\
\hline $\begin{array}{l}\text { Chronic CNS infectious } \\
\text { diseases }\end{array}$ & Not specified $\uparrow$ & hu & $\begin{array}{l}\text { HIV, measles infection and JC-papovavirus } \\
\text { infection }\end{array}$ & [2] \\
\hline Huntington's disease & Neurons $\downarrow$, Astrocytes $\uparrow$ & hu & {$[51]$} & \\
\hline $\begin{array}{l}\text { Parkinson's disease, Diffuse } \\
\text { lewy body disease }\end{array}$ & $\begin{array}{l}\text { Neurons (PD) } \downarrow, \text { Not specified } \\
\text { (DLBD) } \uparrow, \text { Astrocytes } \uparrow\end{array}$ & hu & $\begin{array}{l}\text { Soluble CD95 is significantly increased in } \\
\text { caudate and putamen and correlate with } \\
\text { TNF, IL-1 and IL-6 }\end{array}$ & $\begin{array}{l}{[2,33} \\
51,52]\end{array}$ \\
\hline Creutzfeldt-Jakob disease & Purkinje cells $\uparrow$, Golgi cells $\uparrow$ & hu & $\begin{array}{l}\text { Caspase } 3 \text {, ERK activation, BAX, Bcl, N- } \\
\text { myc upregulated in Purkinje cells. No cell } \\
\text { death but loss of dendritic spines. }\end{array}$ & {$[53]$} \\
\hline Anterograde degeneration & Astrocytes $\uparrow$ & ra & No Tunel positive cells & {$[54]$} \\
\hline Inflammation & Microglia $\uparrow$ & $\mathrm{mu}$ & $\begin{array}{l}\text { After repeated i.p. administration of LPS or } \\
\text { treatment with IFN- } \gamma \text { and TNF- } \alpha\end{array}$ & {$[55,56]$} \\
\hline ALS/development & Motor neurons & mu, hu & $\begin{array}{l}\text { Increased at time of motorneuron pruning } \\
\text { during development and in cells from } \\
\text { SOD1 mutant mice. In vitro, neurons } \\
\text { become sensitive to CD95 ligation and cell } \\
\text { death can be blocked by caspase } 8, \text { p38 } \\
\text { SAPK or nNOS inhibition. }\end{array}$ & {$[57-59]$} \\
\hline Others & Not specified $\uparrow$ & hu & $\begin{array}{l}\text { Pick's disease, progressive supranuclear } \\
\text { palsy, multiple system atrophy }\end{array}$ & [33] \\
\hline
\end{tabular}


Tab. 2. Regulation of CD95L in CNS-related diseases.

\begin{tabular}{|c|c|c|c|c|}
\hline & $\begin{array}{l}\text { Cell-type } \\
\text { (CD95L regulation) }\end{array}$ & Species & Comments & Ref. \\
\hline Alzheimer's disease & Neurons $\uparrow$, Astrocytes $\uparrow$ & hu, mu & Surrounding plaques & {$[27,30]$} \\
\hline Ischemia/stroke & $\begin{array}{l}\text { Neurons } \uparrow, \text { Not specified } \uparrow \\
\text { Microglia } \uparrow\end{array}$ & mu, ra & $\begin{array}{l}\text { Lpr, gld, and TNF k.o. mice have decreased } \\
\text { infarct volume. Oxidative stress upregulate } \\
\text { CD95L in vitro. }\end{array}$ & $\begin{array}{l}{[6,7,36} \\
39,60,61]\end{array}$ \\
\hline $\begin{array}{l}\text { Pontosubicular neuron } \\
\text { necrosis }\end{array}$ & Astrocytes $\uparrow$, Microglia $\uparrow$ & hu & {$[40]$} & \\
\hline Traumatic brain injury & $\begin{array}{l}\text { Astrocytes } \uparrow, \text { Neurons } \uparrow, \\
\text { Microglia } \uparrow, \text { CSF levels } \uparrow\end{array}$ & $\mathrm{ra}, \mathrm{mu}, \mathrm{hu}$ & {$[9,10]$} & \\
\hline Spinal chord compression & $\begin{array}{l}\text { Not specified } \uparrow \text { microglia } \uparrow, \\
\text { astrocytes } \uparrow\end{array}$ & ra & $\begin{array}{l}\text { Oligodendrocytes, astrocytes and microglia } \\
\text { appear to be CD } 95 \text { sensitive }\end{array}$ & {$[44,45]$} \\
\hline MS/EAE & $\begin{array}{l}\text { Microglia } \uparrow \text { astrocytes } \uparrow \\
\text { oligodendrocytes } \uparrow\end{array}$ & hu, mu & $\begin{array}{l}\text { In MS or during early acute phase of EAE, } \\
\text { co-localised with TUNEL- and CD95-positive } \\
\text { glial cells. }\end{array}$ & {$[2,46-48]$} \\
\hline Virus induced demyelination. & Astrocytes $\uparrow$ & $\mathrm{mu}$ & $\begin{array}{l}\text { Astrocytes infected with Theiler's murine } \\
\text { encephalomyelitis virus upregulate CD95L. }\end{array}$ & [49] \\
\hline Huntington's disease & Neurons $\downarrow$, Astrocytes $\uparrow$ & hu & Reactive astrocytes & {$[51]$} \\
\hline Parkinson's disease & Neurons $\downarrow$, Astrocytes $\uparrow$ & hu & Reactive astrocytes & [51] \\
\hline Creutzfeldt-Jakob disease & $\begin{array}{l}\text { Purkinje cells } \uparrow, \text { reactive } \\
\text { astrocytes } \uparrow\end{array}$ & hu & $\begin{array}{l}\text { Also in reactive astrocytes in } \\
\text { Olivopontocerebellar atrophy } \uparrow\end{array}$ & [53] \\
\hline Anterograde degeneration & Astrocytes $\uparrow$ & ra & No TUNEL positive cells & [54] \\
\hline HIV encephalitis & Whole brain $\uparrow$ & hu & $\begin{array}{l}\text { Only in HIV patients with encephalitis, on } \\
\text { astrocytes infected in vitro. }\end{array}$ & [62] \\
\hline Inflammation & Microglia $\uparrow$ & $\mathrm{mu}$ & After repeated i.p. administration of LPS & {$[55]$} \\
\hline Others & Motor neurons $\uparrow$ & $\mathrm{mu}$ & During development & [59] \\
\hline
\end{tabular}

thermore, we present evidence suggesting that astrocytes respond to cytokine treatment by upregulating pro- and antiapoptotic genes. In the case of CD95 stimulation, the changed expression clearly tips the death-life balance towards apoptotic-like deaths.

\section{Acknowledgments}

The excellent technical assistance and input of Andreas Rassov, Søren Hofman Christiansen, and Søren Lund is gratefully acknowledged. We are indebted to Drs. Julia Lotharius, Kenneth Thirstrup, Søren Wilken Rasmussen, Jens Gerwien and Jan Egebjerg for valuable contributions and insightful discussions during the course of this work.

\section{References}

[1] Eng, L. F., Ghirnikar, R. S., Lee, Y. L. (2000) Glial fibrillary acidic protein: GFAP-thirty-one years (1969-2000). Neurochem. Res. 25: 1439-1451.

[2] Dowling, P., Shang, G., Raval, S., Menonna, J., Cook, S., Husar,W. (1996) Involvement of the CD95 (APO-1/Fas) receptor/ligand system in multiple sclerosis brain. J. Exp. Med. 184: 1513-1518.

[3] Nagata, S. and Golstein, P. (1995) The Fas death factor. Science 267: 1449-1456.
[4] Wajant, H., Pfizenmaier, K., Scheurich, P. (2003) Nonapoptotic Fas signaling. Cytokine Growth Factor Rev. 14: 53-66.

[5] Saas, P., Boucraut, J., Quiquerez, A. L., Schnuriger, V., Perrin, G., Desplat-Jego, S., Bernard, D., Walker, P. R., Dietrich, P. Y. (1999) CD95 (Fas/Apo-1) as a receptor governing astrocyte apoptotic or inflammatory responses: a key role in brain inflammation?. J. Immunol. 162: 2326-2333.

[6] Martin-Villalba, A., Herr, I., Jeremias, I., Hahne, M., Brandt, R., Vogel, J., Schenkel, J., Herdegen, T., Debatin, K. M. (1999) CD95 ligand (Fas-L/APO-1L) and tumor necrosis factor-related apoptosis-inducing ligand mediate ischemiainduced apoptosis in neurons. J. Neurosci. 19: 3809-3817.

[7] Martin-Villalba, A., Hahne, M., Kleber, S., Vogel, J., Falk, W., Schenkel, J., Krammer, P. H. (2001) Therapeutic neutralization of CD95-ligand and TNF attenuates brain damage in stroke. Cell Death Differ. 8: 679-686.

[8] Boutin, H., LeFeuvre, R. A., Horai, R., Asano, M., Iwakura, Y., Rothwell, N. J. (2001) Role of IL-1alpha and IL-1beta in ischemic brain damage. J. Neurosci. 21: 5528-5534.

[9] Qiu, J., Whalen, M. J., Lowenstein, P., Fiskum, G., Fahy, B., Darwish, R., Aarabi, ., Yuan, J., Moskowitz, M. A. (2002) Upregulation of the Fas receptor death-inducing signaling complex after traumatic brain injury in mice and humans. J. Neurosci. 22: 3504-3511.

[10] Beer, R., Franz, G., Schopf, M., Reindl, M., Zelger, B., Schmutzhard, E., Poewe, W., Kampfl, A. (2000) Expression 
of Fas and Fas ligand after experimental traumatic brain injury in the rat. J. Cereb. Blood Flow Metab. 20: 669-677.

[11] Beer, R., Franz, G., Krajewski, S., Pike, B. R., Hayes, R. L., Reed, J. C., Wang, K. K., Klimmer, C., Schmutzhard, E., Poewe, W., Kampfl, A. (2001) Temporal and spatial profile of caspase 8 expression and proteolysis after experimental traumatic brain injury. J. Neurochem. 78: 862-873.

[12] Franz, G., Beer, R., Intemann, D., Krajewski, S., Reed, J. C., Engelhardt, K., Pike, B. R., Hayes, R. L., Wang, K. K., Schmutzhard, E., Kampfl, A. (2002) Temporal and spatial profile of Bid cleavage after experimental traumatic brain injury. J. Cereb. Blood Flow Metab. 22: 951-958.

[13] Falsig, J., Latta, M., Leist, M. (2004) Defined inflammatory states in astrocyte cultures: correlation with susceptibility towards CD95-driven apoptosis. J. Neurochem. 88: 181-193.

[14] Weinstein, D. E. (1997) Isolation and Purification of Primary Rodent Astrocytes. Current Protocols in Neuroscience 3.5.1-3.5.9. John Wiley and Sons Inc.

[15] Hughes, T. R., Mao, M., Jones, A. R., Burchard, J., Marton, M. J., Shannon, K. W., Lefkowitz, S. M., Ziman, M., Schelter, J. M., Meyer, M.R., Kobayashi, S., Davis, C., Dai, H., He, Y. D., Stephaniants, S. B., Cavet, G., Walker, W. L., West, A., Coffey, E., Shoemaker, D. D., Stoughton, R., Blanchard, A. P., Friend, S. H., Linsley, P. S. (2001) Expression profiling using microarrays fabricated by an ink-jet oligonucleotide synthesizer. Nat. Biotechnol. 19: 342-347.

[16] Knudsen, S. A biologist's guide to analysis of CDNA microarray data. 2002. New York, Wiley Interscience.

[17] Leist, M. and Jaattela, M. (2001) Four deaths and a funeral: from caspases to alternative mechanisms. Nat. Rev. Mol. Cell. Biol. 2: 589-598.

[18] Condorelli, G., Vigliotta, G., Cafieri, A., Trencia, A., Andalo, P., Oriente, F., Miele, C., Caruso, M., Formisano, P., Beguinot, F. (1999) PED/PEA-15: an anti-apoptotic molecule that regulates FAS/TNFR1-induced apoptosis. Oncogene 18: 4409-4415.

[19] Bissonnette, R. P., Echeverri, F., Mahboubi, A., Green, D. R. (1992) Apoptotic cell death induced by c-myc is inhibited by bcl-2. Nature 359: 552-554.

[20] Suk, K., Kim, S. Y., Kim, H. (2002) Essential role of caspase-11 in activation-induced cell death of rat astrocytes. $J$. Neurochem. 80: 230-238.

[21] Choi, C., Park, J. Y., Lee, J., Lim, J. H., Shin, E. C., Ahn, Y. S., Kim, C. H., Kim, S. J., Kim, J. D., Choi, I. S., Choi, I. H. (1999) Fas ligand and Fas are expressed constitutively in human astrocytes and the expression increases with IL1, IL-6, TNF-alpha, or IFN-gamma. J. Immunol. 162: $1889-1895$.

[22] Wosik, K., Becher, B., Ezman, A., Nalbantoglu, J., Antel, J. P. (2001) Caspase 8 expression and signaling in Fas injuryresistant human fetal astrocytes. Glia 33: 217-224.

[23] Ying, W., Sevigny, M. B., Chen, Y., Swanson, R. A. (2001) Poly(ADP-ribose) glycohydrolase mediates oxidative and excitotoxic neuronal death. Proc. Natl. Acad. Sci. U.S.A. 98: 12227-12232.

[24] Lee, S. J., Zhou, T., Choi, C., Wang, Z., Benveniste, E. N. (2000) Differential regulation and function of Fas expression on glial cells. J. Immunol. 164: 1277-1285.

[25] Saas, P., Walker, P. R., Quiquerez, A. L., Chalmers, D. E., Arrighi, J. F., Lienard, A., Boucraut, J., Dietrich, P.Y. (2002) A self-defence mechanism of astrocytes against Fas-mediated death involving interleukin-8 and CXCR2. Neuroreport 13: 1921-1924.

[26] Malipiero, U., Frei, K., Spanaus, K. S., Agresti, C., Lassmann, H., Hahne, M., Tschopp, J., Eugster, H. P., Fontana, A. (1997) Myelin oligodendrocyte glycoprotein-induced autoimmune encephalomyelitis is chronic/relapsing in perforin knockout mice, but monophasic in Fas- and Fas ligand-deficient Ipr and gld mice. Eur. J. Immunol. 27: 3151-3160.

[27] Su, J. H., Anderson, A. J., Cribbs, D. H., Tu, C., Tong, L., Kesslack, P., Cotman, C. W. (2003) Fas and Fas ligand are associated with neuritic degeneration in the $A D$ brain and participate in beta-amyloid-induced neuronal death. Neurobiol. Dis. 12: 182-193.

[28] Ethell, D. W., Kinloch, R., Green, D. R. (2002) Metalloproteinase shedding of Fas ligand regulates beta-amyloid neurotoxicity. Curr. Biol. 12: 1595-1600.

[29] Nishimura, T., Akiyama, H., Yonehara, S., Kondo, H., Ikeda, K., Kato, M., Iseki, E., Kosaka, K. (1995) Fas antigen expression in brains of patients with Alzheimer-type dementia. Brain Res. 695: 137-145.

[30] Ferrer, I., Puig, B., Krupinsk, J., Carmona, M., Blanco, R. (2001) Fas and Fas ligand expression in Alzheimer's disease. Acta Neuropathol. 102: 121-131.

[31] de la Monte, S. M., Sohn, Y. K., Wands, J. R. (1997) Correlates of p53- and Fas (CD95)-mediated apoptosis in Alzheimer's disease. J. Neurol. Sci. 152: 73-83.

[32] Seidl, R., Fang-Kircher, S., Bidmon, B., Cairns, N., Lubec, G. (1999) Apoptosis-associated proteins p53 and APO-1/ Fas (CD95) in brains of adult patients with Down syndrome. Neurosci. Lett. 16: 438-412.

[33] de la Monte, S. M., Sohn, Y. K., Ganju, N., Wands, J. R. (1998) P53- and CD95-associated apoptosis in neurodegenerative diseases. Lab Invest. 78: 401-411.

[34] Matsuyama, T., Hata, R., Tagaya, M., Yamamoto, Y., Nakajima, T., Furuyama, J., Wanaka, A., Sugita, M. (1994) Fas antigen mRNA induction in postischemic murine brain. Brain Res. 657: 342-346.

[35] Tarkowski, E., Rosengren, L., Blomstrand, C., Jensen, C., Ekholm, S., Tarkowski, A. (1999) Intrathecal expression of proteins regulating apoptosis in acute stroke. Stroke $\mathbf{3 0}$ : 321-327.

[36] Padosch, S. A., Popp, E., Vogel, P., Bottiger, B. W. (2003) Altered protein expression levels of Fas/CD95 and Fas ligand in differentially vulnerable brain areas in rats after global cerebral ischemia. Neurosci. Lett. 338: 247-251. 
[37] Jin, K., Graham, S. H., Mao, X., Nagayama, T., Simon, R. P., Greenberg, D. A. (2001) Fas (CD95) may mediate delayed cell death in hippocampal CA1 sector after global cerebral ischemia. J. Cereb. Blood Flow Metab. 21: $1411-1421$.

[38] Phanithi, P. B., Yoshida, Y., Santana, A., Su, M., Kawamura, S., Yasui, N. (2000) Mild hypothermia mitigates postischemic neuronal death following focal cerebral ischemia in rat brain: immunohistochemical study of Fas, caspase-3 and TUNEL. Neuropathology 20: 273-282.

[39] Rosenbaum, D. M., Gupta, G., D'Amore, J., Singh, M., Weidenheim, K., Zhang, H., Kessler, J. A. (2000) Fas (CD95/ APO-1) plays a role in the pathophysiology of focal cerebral ischemia. J Neurosci. Res. 61: 686-692.

[40] van Landeghem, F. K., Felderhoff-Mueser, U., Moysich, A., Stadelmann, C., Obladen, M., Bruck, W., Buhrer, C. (2002) Fas (CD95/Apo-1)/Fas ligand expression in neonates with pontosubicular neuron necrosis. Pediatr. Res. 51: $129-135$.

[41] Tan, Z., Levid, J., Schreiber, S. S. (2001) Increased expression of Fas (CD95/APO-1) in adult rat brain after kainate-induced seizures. Neuroreport 12: 1979-1982.

[42] Tan, Z., Sankar, R., Tu, W., Shin, D., Liu, H., Wasterlain, C. G., Schreiber, S. S. (2002) Immunohistochemical study of p53-associated proteins in rat brain following lithium-pilocarpine status epilepticus. Brain Res. 929: 129-138.

[43] Lenzlinger, P. M., Marx, A., Trentz, O., Kossmann, T., Morganti-Kossmann, M. C. (2002) Prolonged intrathecal release of soluble Fas following severe traumatic brain injury in humans. J. Neuroimmunol. 122: 167-162.

[44] Li, G. L., Farooque, M., Olsson, Y. (2000) Changes of Fas and Fas ligand immunoreactivity after compression trauma to rat spinal cord. Acta Neuropathol. (Berl) 100: 75-81.

[45] Casha, S., Yu, W. R., Fehlings, M. G. (2001) Oligodendroglial apoptosis occurs along degenerating axons and is associated with FAS and p75 expression following spinal cord injury in the rat. Neuroscience 103: 203-218.

[46] D'Souza, S. D., Bonetti, B., Balasingam, V., Cashman, N. R., Barker, P. A., Troutt, A. B., Raine, C. S., Antel, J. P. (1996) Multiple sclerosis: Fas signaling in oligodendrocyte cell death. J. Exp. Med. 184: 2361-2370.

[47] Bonetti, B., Pohl, J., Gao, Y. L., Raine, C. S. (1997) Cell death during autoimmune demyelination: effector but not target cells are eliminated by apoptosis. J. Immunol. 159: 5733-5741.

[48] Bonetti, B. and Raine, C. S. (1997) Multiple sclerosis: oligodendrocytes display cell death-related molecules in situ but do not undergo apoptosis. Ann Neurol. 42: 74-84.

[49] Palma, J. P., Yauch, R. L., Lang, S., Kim, B. S. (1999) Potential role of CD4+ T cell-mediated apoptosis of activated astrocytes in Theiler's virus-induced demyelination. J. Immunol. 162: 6543-6551.

[50] Fassbender, K., Eschenfelder, C., Hennerici, M. (1999) Fas (APO-1/CD95) in inflammatory CNS diseases: intrathecal release in bacterial meningitis. J. Neuroimmunol. 93: $122-125$.

[51] Ferrer, I., Blanco, R., Cutillas, B., Ambrosio, S. (2000) Fas and Fas- $L$ expression in Huntington's disease and Parkinson's disease. Neuropathol. Appl. Neurobiol. 26: 424-433.

[52] Mogi, M., Harada, M., Kondo, T., Mizuno, Y., Narabayashi, H., Riederer, P., Nagatsu, T. (1996) The soluble form of Fas molecule is elevated in parkinsonian brain tissues. Neurosci. Lett. 220: 195-198.

[53] Puig, B., Ferrer, I. (2001) Cell death signaling in the cerebellum in Creutzfeldt-Jakob disease. Acta Neuropathol. (Berl) 102: 207-215.

[54] Bechmann, I., Lossau, S., Steiner, B., Mor, G., Gimsa, U., Nitsch, R. (2000) Reactive astrocytes upregulate Fas (CD95) and Fas ligand (CD95L) expression but do not undergo programmed cell death during the course of anterograde degeneration. Glia 32: 25-41.

[55] Terrazzino, S., Bauleo, A., Baldan, A., Leon, A. (2002) Peripheral LPS administrations up-regulate Fas and FasL on brain microglial cells: a brain protective or pathogenic event? J. Neuroimmunol. 124: 45-53.

[56] Spanaus, K. S., Schlapbach, R., Fontana, A. (1998) TNFalpha and IFN-gamma render microglia sensitive to Fas ligand-induced apoptosis by induction of Fas expression and down-regulation of $\mathrm{Bcl}-2$ and $\mathrm{Bcl}-\mathrm{xL}$. Eur. J. Immunol. 28: 4398-4408.

[57] Raoul, C., Estevez, A. G., Nishimune, H., Cleveland, D. W., deLapeyriere, O., Henderson, C. E., Haase, G., Pettmann, B. (2002) Motoneuron death triggered by a specific pathway downstream of Fas. potentiation by ALS-linked SOD1 mutations. Neuron 35: 1067-1083.

[58] Lautrette, C., Giraud, S., Vermot-Desroches, C., Preud'homme, J. L., Jauberteau, M. O. (2003) Expression of a functional Fas death receptor by human foetal motoneurons. Neuroscience 119: 377-385.

[59] Raoul, C., Henderson, C. E., Pettmann, B. (1999) Programmed cell death of embryonic motoneurons triggered through the Fas death receptor. J. Cell Biol. 147: 1049-1062.

[60] Vogt, M., Bauer, M. K., Ferrari, D., Schulze-Osthoff, K. (1998) Oxidative stress and hypoxia/reoxygenation trigger CD95 (APO-1/Fas) ligand expression in microglial cells. FEBS Lett. 429: 67-72.

[61] Facchinetti, F., Furegato, S., Terrazzino, S., Leon, A. (2002) $\mathrm{H}(2) \mathrm{O}(2)$ induces upregulation of Fas and Fas ligand expression in NGF-differentiated PC12 cells: modulation by cAMP. J. Neurosci. Res. 69: 178-188.

[62] Ghorpade, A., Holter, S., Borgmann, K., Persidsky, R., Wu, L. (2003) HIV-1 and IL-1 beta regulate Fas ligand expression in human astrocytes through the NF-kappa B pathway. J. Neuroimmunol. 141: 141-149. 